\title{
ANGELOMORPHIC CATEGORIES, EARLY CHRISTOLOGY AND DISCIPLESHIP, WITH SPECIAL REFERENCE TO LUKE-ACTS ${ }^{1}$
}

\section{Crispin H.T. Fletcher-Louis}

The thesis introduction orients this project methodologically within the new religionsgeschichte Schule and justifies a focus on angelic categories as a background to early Christology. The assumption that 'apocalyptic' is essentially dualistic is challenged, and attention is drawn to studies which have highlighted the human attainment of an angelomorphic identity. This phenomenon holds particular relevance for the worship of Christ, who is not an 'angel' but possesses angelic characteristics. It also offers a bridge to later 'two powers in heaven' debates, which presume a binitarian theology (or Christology).

The choice of Luke-Acts as a suitable case study for our approach is justified, since the work: (a) is thoroughly Jewish in theology and culture; (b) has a high Christology; and (c) is at home in the world of Jewish apocalyptic (and mystical) speculation. A natural theology in which humanity is divine (Acts 17) is also noted as a context for the exploration of angelomorphic soteriology in Luke-Acts.

In the first section of the thesis, the first task is to examine the evidence for an angelomorphic Christology in Luke-Acts both after the resurrection (and ascension) and during Jesus' earthly life. An angelophanic form is proposed for Luke 5:1-11. The dominant interpretation of the transfiguration as a proleptic glorification, without any reference to Jesus' divinity, is questioned. The proleptic does not

${ }^{1}$ Crispin H.T. Fletcher-Louis, An Examination of the Relevance of Angelomorphic Categories for the Understanding of Early Christology and Discipleship, with Special Reference to Luke-Acts (unpublished D.Phil. thesis, University of Oxford, 1995); supervisor: Professor C.C. Rowland. 
do justice to details of the account. In comparison with the transformation of Enoch (Metatron), the deification of Moses, and the similarity to the angelophany in Daniel 10, the transfiguration should be read as either a fully attained angelisation to a new identity, or a revelation of one already possessed. Jesus' 'divine' identity should also be taken seriously.

These studies demonstrate the importance of angelic categories for the identity of the risen Jesus. The fluidity between God and Jesus and God and his angel suggests a fluidity between Jesus and an angel; a suggestion corroborated by a form-critical examination of the Christophany at Paul's conversion. The pharisaic position in the debate at Acts 23:8-9 reveals the possibility of an 'angel' Christology on the immediate horizon of Luke's history-of-religions context. Finally, in Luke 24 angelic categories are part of a narrative dialectic which articulates both Jesus' full humanity and full divinity. Initially, Jesus is compared to the Old Testament angel of the LORD (Lk. 24:13-35). This is then balanced by an affirmation of Jesus' more-than-angelic humanity in the eating of food (Lk. 24:36-43).

The second task is to assemble evidence for Lukan belief in an angelomorphic soteriology. An allegorical reading is suggested for Luke 15:1-10, in which the disciples' joy in the company of Jesus is an imitation or incarnation of the joy of the angels before God. At Luke 20:34-38, concerning the levirate law, the view that Jesus envisages a this-life celibacy in anticipation of the angelic life is carefully considered. In support of previous arguments for this view, a linguistic and conceptual link to Luke 15:11-32 is proposed. There, it is suggested, the son's passage from death to life $(15: 24,32)$ has resulted in the attainment of an angelomorphic sonship symbolised by the investiture scene in 15:22. Unequivocal confirmation of Luke's interest in the angelic identity of the righteous is provided by his description of Stephen's face in Acts 6:15. There the angelic is not simply a proleptic anticipation of the martyr's afterlife but in various ways is related to his experience of the Spirit in the present. 
All this calls for a detailed examination of the extent and shape of a Jewish belief in a human angelomorphic identity. This is found in the second section of the thesis, which begins with a presentation of evidence for an angelomorphic view of kingship, priesthood and prophecy rooted in the Old Testament. In two traditions, angelomorphic priesthood is related to the reception of worship by a human figure. Beyond the biblical period, we examine a succession of angelomorphic heroes; among them Enoch, Noah, Jacob/Israel and Moses, whose angelomorphism is related to that of Adam. Again, Enoch and Adam traditions relate the angelomorphic identity to the reception of worship. Regarding the Similitudes, a thoroughgoing integration of the human and heavenly, Enoch and Son of Man, is demonstrated.

In various texts, there is an oscillation between the angelomorphic identity of the corporate and individual identity of Jacob/Israel. In the case of Moses, the common judgement that the divine Moses is a tradition peculiar to Hellenistic Judaism is revised; the tradition is well rooted in 'orthodox' Palestinian Judaism. The Dead Sea Scrolls, the Therapeutae and the Testament of Job furnish evidence of communities with an angelomorphic self-perception. Finally, a new reading of Daniel 7-12 is proposed according to which the 'one like a son of man' and the 'saints of the Most High' are allowed both a human and angelic referent.

In the third section, Luke-Acts is considered further in the light of this history-of-religions study. A reappraisal of the material examined in the first section of the thesis confirms, in the light of specific Jewish traditions, issues first considered there, such as the life of angelomorphic celibacy and the Lukan differentiation in understanding of the transfiguration between transformation and manifestation. We then offer an examination of the identity of Jesus as the angelomorphic Son of Man. Given our understanding of the Jewish Son of Man figure as both human and angelic (divine) (section 2) we argue that the two categories of Son of Man sayings, present and future, can now be integrated. For the 'future', sayings we highlight the human, angelic and divine contours of the Son of Man's identity, particularly in Luke's version of Mark 8:38 (Lk. 9:26). The 
cosmic Son of Man of Luke 17:24 is interpreted in the light of interest in angelomorphic gigantism, and a recently released Aramaic Levi fragment from Qumran.

We argue further that the Son of Man in Luke 12:8-9 is both present and future in a way which articulates a fundamental dialectic within Jesus' identity, binding together all other Son of Man sayings. On analogy with the Similitudes of Enoch and the Prayer of Joseph, where a human individual has an angelic alter ego with a different name, the Son of Man in Luke 12:8-9 is the heavenly name of the earthly Jesus. The confession or denial of Jesus transfers a criterion of membership of God's people in the Similitudes from God himself to the Son of Man.

The present Son of Man sayings also betray the angelomorphic identity of this title. Otherwise the gospel emphasis on suffering and humanity is a conscious critique of Jewish expectation. This is seen particularly in Luke 7:34. This saying is thoroughly apocalyptic, and specifically angelomorphic, in scope. As the angelomorphic Son of Man, Jesus would not have been expected (a) to eat ordinary earthly food, and (b) to have associated with the unclean. Acts 7:55-56 can be understood as a fulfilment of Luke 12:8-9 with Jesus, in his angelomorphic mode, standing between heaven and earth.

The Lukan Son of Man is the most comprehensive expression of Jesus' angelomorphic identity, articulating both his full humanity and divinity, and holding together other expressions of that identity at, for example, Luke 5:1-11 and 9:28-36.

This thesis confirms that (a) angelic categories are relevant for the formation of early Christian thought, and that (b) Luke is a particularly good example thereof. It also provides suggestions as to possible implications for the current debate within the new history-of-religions school and for the shape of New Testament theology. 